\title{
Socio-Cultural-Literary Survey of American Literature
}

\author{
Dr. Vinay Bhogle \\ Asst Professor, Dept. of English \\ Degloor College \\ Degloor, Maharashtra, India \\ vinaybhogle2@gmail.com
}

\begin{abstract}
It very well may be said that American Literature may have started in 1493 when Columbus composed his acclaimed letters to King Ferdinand of Spain. Different travellers and explorers, who followed, composed letters to their companions and family members at home. These 'letters home' mark the start of the put down account of the threats they needed to confront, yet in addition to the marvels that should have been seen all over. The interest was energized at home in light of these letters. The letters gave reasonable and striking records. An ever increasing number of individuals were enticed to cruise for the New World to settle there. Such courageous spirits came not from England alone, yet these spirits originated from most different nations of Europe-Spain, Portugal, France, Holland, and numerous others. Along these lines, there established the framework of the 'solidarity in decent variety' which is such a noticeable element of American culture.
\end{abstract}

Keywords: Socio-culture, society, democracy, commerce and trade, community.

In 1607, Jamestown was the main effective English settlement in North America. At that point came the Pilgrim Fathers in the boat called the Mayflower. They established the Plymouth Colony in Massachusetts. The most punctual American essayists were truly 
European scholars living in America. In spite of the fact that they may have left Europe quite a while past, their composing was plainly affected by European scholars. There was, initially, an impersonation of European and specifically English writing. It doesn't imply that there was no writing in the provincial time frame. Pilgrim American writing portrays the perilous experience, the difficult work, and troublesome choices that went into the way toward building a country.

The Puritans were the early colonizers who settled round New England. Rigidity practiced impressive impact on the development of American writing. The most punctual of the Puritan artists was Anne Bradstreet (1612-1773). Her sonnets were distributed under the title The Tenth Muse Lately Sprung up in America. Another writer Michael Wigglesworth (1631-1705) made The Day out of Doom. Different essayists who added to writing from the provincial time frame were Edward Taylor, Thomas Godfrey, Cotton Mather, Jonathan Edwards, and Benjamin Franklin. The War of Independence was over by 1781 . The different states had met up to battle against British oppression and unreasonable laws made in Great Britain. The war brought political autonomy, however artistic and social freedom was at this point to come. Another significant improvement of the early long stretches of the century was the ascent of American majority rule government. The progressive compositions of Rousseau and different producers of the French Revolution and the French Revolution itself with the standards' Liberty, Equality, and Fraternity', propelled Americans. Walt Whitman is the best writer of American voice at the International level. He is the principal artist who got well known as the main American writer. His 'Leaves of Grass' has been known as 'the Bible of Democracy.'

Particularly in America, where the fair cycle brought the individuals into close experience with and touchy reaction to social powers, the writing reacted rapidly to such weights. These seventy five percent of a century have encountered overall changes, for 
example, the two World Wars, the spread of Communism and the ascent and fall of Fascism, and such limited or public occasions as the incomparable Dust Bowl debacle to Mid-West horticulture, the Great Depression of the thirties, and the restriction test of the twenties. The expanding urbanization and the centralization of populace in rural territories, the approach of the vehicle, the radio, the moving picture theatres, and the zap of provincial America have been factors changing the social and artistic existence of the country. We discover there were the Southern journalists, New England essayists, and Western and Mid-Western scholars. We have had a writing of the American Indian, the Negro, the Jew; we have had the issue of racial absorption as a reason for writing. What's more, we have had resistance to digestion in our writing. The railways and parkways, the portability given by the car, public inclusion by radio, TV, press affiliations, Magazines, and publicizing efforts, have experienced the resistance of those backers of the neighbourhood and novel social qualities to be found in disconnected pockets with argumentative varieties and curious folkways. Accordingly a consistent basic evaluation of variables in American culture has given American writing an unsure self-analysis. The social changes quickened by the war were to change the life of the country in angles influencing all periods of individual and public activity under the administration of Woodrow Wilson. The American public gave themselves over to an expanded and outlandish optimism. The period from 1910 to 1920 now and then is known as the "adolescents" and it has numerous likenesses to the state of high school youth. It was for the America time of improvement as a country and change in social examples. Woodrow Wilson, the school educator turning into the President, was a tranquil and noble pioneer for such convincing change as were clearing the nation. Wilson's program of homegrown improvement, with which he started his administration and which was enormously required by the country, was hindered by the war in the mid-year of 1914. The war brought modern development, expanded work, higher wages, and more prominent system. The improvement 
in medication and general wellbeing expanded the life expectancy. Youngsters could pick up work all alone - and they did. Ladies entered industry and different vocations outside the home in enormous numbers. The great many youngsters in the equipped administrations were looking for new places, learning new ways.

We find that till in the early long stretches of the seventeenth century, the entire of Western America had been colonized. Different people groups of Europe, who got comfortable this aspect of the new mainland, were before long consumed into the prevailing British gathering and obtained its way of life and methods of thought. These Atlantic Provinces turned into a homogenous gathering by the early long stretches of the seventeenth century. Contrasts were subjected to the regular culture, and consequently we get that ' assorted variety inside solidarity ' which is such a main attribute of American writing and the American lifestyle. This meeting up, this sentiment of unity, was additionally fortified by common instruction, the new age got in colleges and schools. The main American college, the Harvard University, was established by the early Puritan pioneers, and an ever increasing number of colleges and schools jumped up with the progression of time. Youngsters from the different Atlantic states ran to these focuses of learning, and the adolescent from one settlement blended and traded sees with those from different provinces. This united them close. There was the beginning of public awareness.

Walt Whitman was conceived on May 31, 1819. He distributed the main release of the Leaves of Grass on July 4, 1855. It currently positions with the everlasting works of art of world writing. In Leaves of Grass, he commends himself, and in praising himself, he observes America moreover. Recorded as a hard copy of himself, he composes of his age and of his nation. The 'I' whom he celebrates in his book isn't Whitman, an unequivocal authentic character, however the normal American, the majority of America. This makes him without a moment's delay the artist of popular government and the artist of America. Whitman's Leaves 
of Grass which once considered as "the statement of a monster," is currently viewed as "The Bible of Democracy." It is the epic of majority rules system. We have the utilization of emblematic components in Leaves of Grass. The 'I' in Whitman's verse doesn't represent the artist alone. It represents the advanced American, the cutting edge man, or even Everyman. The 'I' may even represent a warrior on the front line, or a comet hurrying through the sky.

Mark Twain is one of the better-known figures throughout the entire existence of American fiction. He is the mainstream both in Europe and America. His magnum opus Huckleberry Finn is an incredible world-book. It is an experience story. It tends to be perused and deciphered on a few levels. The two characters and episodes are emblematic. Huck's excursion is emblematic of soul's excursion to paradise. The pontoon is the image of harmony. The stream Mississippi represents an unmistakable culture. Jim is the Negro slave of Miss Watson. He is dark with a white heart. He is be fooled by Tom. The epic shows Mark Twain's humour at its best.

Emily Dickinson was the best lady artist of America. She was conceived on December 10, 1830. Emily Dickinson never wedded. She started composing sonnets during her twenties. Her sonnets were named 'The Poems of Emily Dickinson.' Her verse comprises of verses, and the greater part of them is short verses. They are an outflow of her strongly felt enthusiastic or mental states and extreme otherworldly encounters. She is likewise an incredible nature-writer and some of her verses manage nature, yet nature in her is constantly suffused with the artist's own feelings. We have the excellence of the dusk and the dawn, the Moon, the magnificence of blossoms and trees, the seasons in her verse. She is additionally an extraordinary love writer. Emily lived like a religious recluse, wearing white; still, she has thought of her sonnets having love as a profoundly felt individual feeling.

American Drama denotes an intriguing connection between the writing of the war decade and that of the twenties. Crafted by Ibsen, Shaw, and other incredible European 
dramatists had far eclipsed anything occurring in American venues up to the appearance of Eugene O'Neill. The way was ready for O'Neill through the intrigue appeared in dramatization by two novice bunches in New York, the Washington Square Players, and the Provincetown Theatre.

We find that before Eugene O'Neill as a dramatist, the American show was totally separated from life and needed inventiveness. The writers were impersonating the British and the European plays. The show of the past occasions was fake, business, and ordinary, for the most part composed for the diversion of tired finance managers and labourers. A large number of labourers went to the city because of the modern upset. They had cash to delight themselves by watching a play, be it a drama or a joke. They had a desire for a play. The play, regardless of whether it was a parody, misfortune, parody, history, or an issue play had amusement esteem. It made progress among the crowd, youthful or old. In this way, they empowered the creation of plays that were far eliminated from life and visual allure however loaded with the gadgets of Melodrama.

Like the free performance centers of Europe, the little or network theatres grew up everywhere on the country to dismiss the smooth, shallow diversion which the traders of Broadway were turning out. The development brought about the foundation of an assortment of gatherings composed under different names. Some were called 'little theatres,' others 'Network,' or 'Urban theatres,' the 'College theatre,' and so on and soforthincludingthe other non-Broadway theatre. These were named as 'cross country theatre,' however the names never got on.

The three principle divisions of the American performance centre are University theatre, Community theatre, and Commercial theatre. The little venues were not bound to huge urban communities; they thrived the towns and towns from Michigan to California. In 1915, the network dramatization restored the three gatherings of itself. 
Symbolism in the broadest feeling of the term is anything which connotes something different; in this sense all words are images. As generally utilized in talking about writing in any case, image is applied uniquely to a word, or set of words that connotes an item or occasion which itself implies something different; that is the words allude to something which recommends a scope of reference past itself. 'Imagery' a name principally connected with a school of French artists writing in the second $50 \%$ of the nineteenth century. It implies the utilization of images to speak to things esp. in workmanship and writing; the images utilized along these lines.

Imagery is an artistic gadget and the essayist utilizes the character, setting, episode, language and communicates his considerations. The writer explains his thoughts, ideas in a short path by utilizing the images in his plays. The psyche of the character is revealed with the utilization of images. 
SMART MOVES JOURNAL IJELLH e-ISSN: 2582-3574 p-ISSN: 2582-4406 VOL. 8, ISSUE 11, NOVEMBER 2020

\section{References}

A Brief History of American Literature, Richard Gray, Willy Blackwell, 2011

A concise history of American Literature, Arvind Mehrotra, OUP, 2015

History of English Literature, Hippolyte Taine, 2012, paperback 